\title{
Peroxisome Proliferator-Activated Receptor (PPAR) $\gamma$ and Retinoid $X$ Receptor (RXR) agonists have complementary effects on glucose and lipid metabolism in human skeletal muscle
}

\author{
B.S. Cha ${ }^{1}$, T. P. Ciaraldi ${ }^{1}$, L. Carter $^{1}$, S. E. Nikoulina ${ }^{1}$, S. Mudaliar ${ }^{1}$, R. Mukherjee ${ }^{2}$, J. R.Paterniti Jr. ${ }^{2}$, R. R.Henry ${ }^{1}$ \\ ${ }^{1}$ Veterans Affairs San Diego Healthcare System, San Diego and Department of Medicine, University of California, San Diego, \\ California, USA \\ ${ }^{2}$ Department of Cardiovascular Research, Ligand Pharmaceuticals, San Diego, California, USA
}

\begin{abstract}
Aims/hypothesis. To determine the independent and potentially synergistic effects of agonists for PPAR $\gamma$ and RXR on glucose and lipid metabolism, as well as gene expression, in human skeletal muscle cell cultures.

Methods. Fully differentiated myotubes from non-diabetic subjects and subjects with Type II (non-insulin-dependent) diabetes mellitus were chronically (2 days) treated with LG100268 (4 $\mu \mathrm{mol} / \mathrm{l})$, an RXR agonist, or troglitazone $(4.6 \mu \mathrm{mol} / \mathrm{l})$, a PPAR $\gamma$ agonist or both, to determine the effects on glucose uptake, activity of glycogen synthase and palmitate oxidation.

Results. The combination of both agents increased glucose uptake $(60 \pm 9 \%$ compared to control subjects) but not either agent alone (16 \pm 9 and $26 \pm 6 \%$ for LG100268 and troglitazone, $p<0.01$, respectively). The agent LG100268 alone had little effect on the activity of glycogen synthase but the effect of troglitazone increased with LG100268 $(p<0.05)$.
\end{abstract}

With chronic exposure, LG100268 upregulated palmitate oxidation $(53 \pm 12 \%$ increase, $p<0.005)$, in a way similar to troglitazone $(68 \pm 23 \%, p<0.005)$. Synergism was observed when both agonists were combined $(146 \pm 38 \%, p<0.005$ vs either agent alone). Treatment with either agent led to about a twofold increase in the expression of fatty acid transporter (FAT/CD36). Troglitazone upregulated PPAR $\gamma$ protein expression, whereas LG100268 had no effect. Furthermore, neither LG100268 nor troglitazone had any effect on the protein expression of $\mathrm{RXR}$ isoforms or PPAR $\alpha$.

Conclusion/interpretation. Co-activation of PPAR $\gamma$ and RXR results in additive or synergistic effects on glucose and lipid metabolism in skeletal muscle, but unlike troglitazone, LG100268 does not alter expression of its own receptor. [Diabetologia (2001) 44: 444-452]

Keywords peroxisome proliferator-activated receptor, retinoid X receptor, skeletal muscle, glucose uptake, palmitate oxidation, FAT/CD36.
Received: 5 October 2000 and in revised form: 8 December 2000

Corresponding author: R.R. Henry, MD, VA San Diego Healthcare System (V111G), 3350 La Jolla Village Drive, San Diego, CA 92161, USA

Abbreviations: CPT-1, Carnitine palmitoyltransferase 1; FBS, fetal bovine serum; FV, fractional velocity; G6P, glucose-6phosphate; GDR, glucose disposal rate; GS, glycogen synthase; GU, glucose uptake; HSMC, human skeletal muscle cells; PMSF, phenylmethylsulfonyl fluoride; Pox, palmitate oxidation; PPAR, peroxisome proliferator-activated receptor; PPRE, peroxisome proliferator response element; RXR, retinoid $\mathrm{X}$ receptor; FAT, fatty acid transporter; UDP, uridine diphosphate.
Skeletal muscle is the principal tissue for insulin-mediated glucose disposal and a major site of peripheral insulin resistance in patients with Type II (non-insulin-dependent) diabetes mellitus $[1,2]$. The thiazolidinedione family of antidiabetic agents have proven effective at treating this insulin resistance. Recently, thiazolidinediones have been identified as high affinity ligands for the nuclear receptor $\operatorname{PPAR} \gamma[3,4]$. The PPAR $\gamma$ binds preferentially to PPAR response elements (PPRE) through cooperative interactions as heterodimers with a partner, RXR, to regulate transcription [5]. Many of these PPAR-binding sites are in the regulatory region of genes involved in lipid 
Table 1. Clinical characteristics of subjects

\begin{tabular}{|c|c|c|c|}
\hline & Combined & Non-diabetic & Type II diabetic \\
\hline Number (F/M) & $34(5 / 29)$ & $15(3 / 12)$ & $19(2 / 17)$ \\
\hline Age (years) & $49 \pm 2$ & $40 \pm 3$ & $56 \pm 2 *$ \\
\hline Body mass index $(\mathrm{kg} / \mathrm{m} 2)$ & $30.3 \pm 1.3$ & $27.1 \pm 1.6$ & $33.0 \pm 1.9^{*}$ \\
\hline Fasting plasma glucose $(\mathrm{mmol} / \mathrm{l})$ & $7.9 \pm 0.6$ & $5.0 \pm 0.1$ & $10.5 \pm 0.7 *$ \\
\hline Fasting plasma insulin (pmol/l) & $105 \pm 28$ & $60 \pm 12$ & $155 \pm 53^{*}$ \\
\hline $\operatorname{GDR}\left(\mathrm{mg} \cdot \mathrm{kg}^{-1} \cdot \mathrm{min}^{-1}\right)$ & $8.4 \pm 0.6$ & $11.3 \pm 0.6$ & $5.8 \pm 0.2 *$ \\
\hline
\end{tabular}

Data are means \pm SEM. GDR, glucose disposal rate from euglycaemic $(5.5-5.5 \mathrm{mmol} / \mathrm{l})$ hyperinsulinemic $\left(1800 \mathrm{pmol}^{\prime} \cdot \mathrm{m}^{-2} \cdot \mathrm{min}^{-1}\right)$ clamp test

$* p<0.05$ compared with non-diabetic subjects

and carbohydrate metabolism [4, 6, 7]. The RXRs play a central part in the regulation of many intracellular receptor signalling pathways and can mediate ligand-dependent transcription, acting as a homodimer or as a heterodimer [8]. Recently, a selective RXR agonist has been shown to have anti diabetic effects in diabetic animal models [9], while also increasing transcriptional responses of PPREs to thiazolidinediones in vitro $[9,10]$.

Although PPAR $\gamma$ appears to be the molecular target for thiazolidinedione action [4], the cellular targets, such as adipose tisssue, skeletal muscle or liver or both, are not well defined. Recent studies from our laboratory have shown that human skeletal muscle cells grown in culture from needle biopsy specimens express the morphological, biochemical and metabolic properties of intact differentiated skeletal muscle $[11,12]$. In the current study, we use the advantages of the muscle culture system to investigate the effects of an RXR agonist (LG100268) and possible interaction with a PPAR $\gamma$ agonist (troglitazone) on glucose and lipid metabolism in skeletal muscle cells from non-diabetic subjects and subjects with Type II diabetes.

\section{Subjects and Methods}

Materials. The AG 1-X8 resin for ion exchange chromatography was purchased from Bio-Rad (Hercules, Calif., USA). All radioisotopes were obtained from Du Pont-New England Nuclear (Boston, Mass., USA). Polyclonal antisera against $\operatorname{RXR} \alpha, \operatorname{RXR} \beta$, and $\operatorname{RXR} \gamma$ were purchased from Santa Cruz Biotechnology (Santa Cruz, Calif., USA). Polyclonal antiserum against PPAR $\gamma$, which recognizes both the $\gamma 1$ and $\gamma 2$ isoforms, was purchased from Biomol (Plymouth Meeting, Pa., USA). A monoclonal antiserum against $\operatorname{PPAR} \alpha$ was generously provided by Dr. D.A. Winegar at Glaxo Wellcome (Research Triangle, N.C., USA). Polyclonal antisera against GLUT1 (AB1340) and GLUT4 (RaIRGT) were purchased from Chemicon International (Temecula, Calif., USA) and East Acres Biologicals (Cambridge, Mass., USA), respectively. A monoclonal antiserum against CD36 was purchased from Serotec (Raleigh, N.C., USA). Etomoxir was purchased from RBI (Natick, Mass., USA). Troglitazone, [( \pm )-5-[4-(6-hydroxy-2,5,7,8-tetramethylchromanny-2-methoxy)-benzyl]-2,4 thiazolinedione], known as a PPAR $\gamma$ agonist, was kindly provided by Dr. A. Saltiel at Parke-Davis Pharmaceuticals (Ann Arbor, Mich., USA). The Retinoid X Receptor agonist, LG100268, 6-[1-(3,5,5,8-8-pentamethyl-5,6,7,8-tetrahydronaphthalen-2-yl)-cyclopropyl]-nicotinic acid, was synthesized at Ligand Pharmaceuticals (San Diego, Calif., USA). Sources of all other common reagents have been listed previously [11, 12].

Subjects. A total of 19 patients with Type II diabetes and 15 non-diabetic subjects provided muscle tissue for the studies. Of the Type II diabetic patients, 17 were treated with oral antidiabetic agents (glipizide-13, glipizide/metformin-3, metformin-1), one with insulin and one with diet only. Diabetic patients had their medication withheld on the morning of biopsy. Non-diabetic control subjects were not taking any medications known to influence glucose and lipid metabolism. Glucose tolerance was measured in all subjects after a $75-\mathrm{g}$ oral glucose tolerance test [13]. Insulin action was analysed by a 3-h euglycaemic $(5.0-5.5 \mathrm{mmol} / \mathrm{l})$ hyperinsulinaemic $\left(1800 \mathrm{pmol} \cdot \mathrm{m}^{-2}\right.$. $\mathrm{min}^{-1}$ ) clamp; the glucose disposal rate (GDR) was measured during the last 30 min of the clamp [14]. The clinical characteristics of the subjects are summarized in Table 1. Because there were no consistent differences in the relative (\% change) effects of troglitazone or LG100268 or both on cells from individual diabetic or non-diabetic subjects, data from all subjects were combined, the characteristics of the combined subjects being shown in Table 1. The experimental protocol was approved by the Committee on Human Investigation of the University of California, San Diego. Informed written consent was obtained from all subjects after the protocol had been explained.

Human muscle cell culture and treatment. The methods for muscle biopsy, skeletal muscle cell isolation, and growth have been described in detail previously $[12,15,16]$. After a 4-day differentiation/fusion period, troglitazone and LG100268, which were dissolved in dimethylsulphoxide (DMSO) DMSO/ ethanol, respectively, were added to cells with medium for another 2 days. The final concentrations of DMSO and ethanol did not exceed $0.05 \%$, respectively. Control cells were treated with vehicle for the same time as troglitazone and LG100268treated cells. Troglitazone and LG100268 treatment had no significant effects on cell differentiation, which was confirmed by measuring skeletal muscle specific $\alpha$-sarcomeric actin protein expression as described in previous reports [12].

Glucose uptake measurement. The procedure used for glucose uptake measurement was a modification of a published procedure [17] and has been described previously [12]. After chronic 
treatment, $17 \mathrm{nmol} / 1$ insulin was added to half of each set of cells for $90 \mathrm{~min}$ in $5 \% \mathrm{CO}_{2}: 95 \% \mathrm{O}_{2}$ incubator before washing and the uptake assay. This procedure measures the uptake (transport plus phosphorylation) of deoxyglucose. The uptake of L-glucose was used to correct each sample for the contribution of diffusion. Protein was measured by the Bradford dyebinding method [18].

Glycogen synthase (GS) activity. We measured GS activity as described previously [12]. The GS activity was assayed at a physiological concentration of substrate $(0.3 \mathrm{mmol} / \mathrm{l}$ uridine diphosphate [UDP]-[ $\left[{ }^{14} \mathrm{C}\right]$ glucose) in parallel incubations with 0.1 and $10 \mathrm{mmol} / \mathrm{l}$ G6P. The GS activity is expressed as nanomoles of UDP- $\left[{ }^{14} \mathrm{C}\right]$ glucose incorporated into glycogen for each $\mathrm{min} \cdot \mathrm{mg}$ protein or as fractional velocity $(\mathrm{FV})$, a percentage of the ratio of activity at $0.1 \mathrm{mmol} / \mathrm{l} \mathrm{G} 6 \mathrm{P} / 10 \mathrm{mmol} / \mathrm{l} \mathrm{G} 6 \mathrm{P}$.

Measurement of palmitate oxidation. The procedure used for assaying palmitate oxidation was a modification of a method established for adherent cells [19]. Cells were incubated in serum-free media containing $10 \mu$ l substrate $\left(\left[9,10-{ }^{3} \mathrm{H}\right]\right.$ palmitic acid, $0.2 \mu \mathrm{Ci}$, final concentration $=2 \mu \mathrm{mol} / \mathrm{l}$ ) in a $95 \% \mathrm{O}_{2}: 5 \%$ $\mathrm{CO}_{2}$ incubator at $37^{\circ} \mathrm{C}$ for $3 \mathrm{~h}$. After incubation, an aliquot $(100 \mu \mathrm{l})$ of the culture medium was placed over an ion-exchange resin and the column washed twice with $0.75 \mathrm{ml}$ of water. Intact palmitate (charged state) was retained by the resin but the oxidized portion of palmitate passed freely through the resin column in the form of water $\left(\mathrm{HO}^{3} \mathrm{H}\right)$.

Beta-oxidation of fatty acids can occur in mitochondria and microsomes. These two pathways were discriminated by the differential sensitivity of FA-CoA uptake across the organelle membrane for inhibition by etomoxir. The CPT1 in the outer mitochondrial membrane is irreversibly inhibited by low levels of etomoxir while CPT analogs in peroxisomes are reversibly inhibited only at much higher etomoxir concentrations [20]. The oxidation of ${ }^{3} \mathrm{H}$-palmitate measured in untreated cells would be considered total oxidation. A second set of cells was treated with a low concentration of etomoxir $(1 \mu \mathrm{mol} / \mathrm{l})$ for $30 \mathrm{~min}$, the agent washed away and the cells permitted to recover for an additional $30 \mathrm{~min}$ before initiation of the oxidation assay. By this operational definition, the difference in activity between these and the control cells would represent mitochondrial palmitate oxidation. A third set of cells was continuously treated with a high $(50 \mu \mathrm{mol} / \mathrm{l})$ etomoxir dose. The difference between the second and third sets of cells was defined as the peroxisomal component of palmitate oxidation. Residual palmitate oxidation observed in the presence of $50 \mu \mathrm{mol} / \mathrm{l}$ etomoxir is considered to occur by other, not yet defined processes.

Cell extraction. Extraction buffer $(20 \mathrm{mmol} / \mathrm{l}$ Tris $\mathrm{HCl}$, $145 \mathrm{mmol} / \mathrm{l} \mathrm{NaCl}, 10 \%$ glycerol, $5 \mathrm{mmol} / \mathrm{l}$ EDTA, $1 \%$ Triton $\mathrm{X}-100,0.5 \%$ nonidet P-40, $200 \mu \mathrm{mol} / 1$ sodium vanadate, $200 \mu \mathrm{mol} / \mathrm{l} \mathrm{PMSF}, 1 \mu \mathrm{mol} / \mathrm{l}$ leupeptin, $1 \mu \mathrm{mol} / 1$ peptstatin, $10 \mu \mathrm{g} / \mathrm{ml}$ aprotinin, $100 \mathrm{mmol} / \mathrm{l} \mathrm{NaF}, 40 \mathrm{mmol} / \mathrm{l}$ sodium pyrophosphate, $\mathrm{pH}$ 7.4) was added to confluent monolayers of fused myotubes, which had been treated for 2 days. Cells were solubulized by incubating for $30 \mathrm{~min}$ on ice, followed by scrapping and centrifugation at $14000 \mathrm{~g}$ for $10 \mathrm{~min}$ at $4^{\circ} \mathrm{C}$. The supernatant fluid, total cell lysate, was analysed for protein content using the Bradford method.

Western blotting. The method for western blot analysis has been described previously [12]. For $\operatorname{RXR} \alpha, \operatorname{RXR} \beta, \operatorname{RXR} \gamma$, PPAR $\gamma$, PPAR $\alpha$ and FAT/CD36, total protein preparations were diluted 3:1 in 4X Laemmli's buffer and boiled for 5 min at $100^{\circ} \mathrm{C}$. For GLUT1 and GLUT4, protein preparations were diluted in Laemmli's buffer without beta-mercaptoethanol and heated for $5 \mathrm{~min}$ at $70^{\circ} \mathrm{C}$. Proteins were separated on $10 \%$ SDS-PAGE gels and then transferred to a nitrocellulose membrane [21]. Specificity of polyclonal antibodies for $\operatorname{RXR} \alpha, \operatorname{RXR} \beta$, and $\operatorname{RXR} \gamma$ proteins was confirmed against standard proteins overexpressed in insect cells. The secondary antibody for $\operatorname{RXR} \alpha, \operatorname{RXR} \beta, \operatorname{RXR} \gamma, \operatorname{PPAR} \gamma, \operatorname{GLUT} 1$, and GLUT4 proteins was antirabbit IgG conjugated with horseradish peroxidase, whereas a similarly conjugated antimouse IgG was used for PPAR $\alpha$ and FAT/CD36. Immune complexes were detected using an enhanced chemiluminescence kit according to the manufacture's instructions, followed by autoradiography. Quantification was done with a scanning laser densitometer (Scan Analysis, Biosoft, Cambridge, UK).

Statistical analysis. Statistical significance was evaluated using Student's $t$ - test, and two-tailed $p$ values were calculated. Paired analysis was done for comparisons of chronic effects of each agonist as well as for individual and combination treatments. Significance was accepted at the $p$ value of less than 0.05 . For the purpose of this study, synergism is taken to be a statistically significant difference between the effect (change from control) of combination treatment and the sum of the individual treatment effects on each response in cells from each subject. Because of the limited number of cells available, not all studies were done in each subject.

\section{Results}

Glucose uptake activity. Chronic administration of troglitazone $(4.6 \mu \mathrm{mol} / \mathrm{l}$ for $2 \mathrm{~d})$ resulted in significant upregulation of glucose uptake in both the basal $\left(17.5 \pm 1.8 \mathrm{vs} 14.5 \pm 1.3 \mathrm{pmol} \cdot \mathrm{mg}^{-1} \cdot \mathrm{min}^{-1}\right.$ in control, $26 \pm 6 \%$ increase, $p<0.01)$ and insulin stimulated $(23.6 \pm 1.8$ vs $19.2 \pm 1.2$ in control subjects, $p<0.01)$ states. LG100268 alone ( $4 \mu \mathrm{mol} / \mathrm{l})$ was also able to increase glucose uptake; marginally at basal (16.0 \pm 1.1 , $16 \pm 9 \%$ increase, $p=0.07$ ) and significantly in the insulin stimulated state $(20.9 \pm 1.1, p<0.05$ compared with control subjects) (Fig.1). When cells were treated with troglitazone and LG100268 together, the increase in glucose uptake was greater than when cells were treated with either agonist alone, both in the basal and insulin-stimulated states $\left(20.9 \pm 1.6\right.$ and $28.3 \pm 1.9 \mathrm{pmol} \cdot \mathrm{mg}^{-1} \cdot \mathrm{min}^{-1}$, $p<0.001$ compared with troglitazone and LG100268 alone, respectively) (Fig.1). The response to combined treatment was also greater than the sum of the individual effects $(60 \pm 9 \%$ increase for basal, $p<0.05$ ), indicating synergism between the agents.

Cells treated with higher concentrations of troglitazone $(11.5 \mu \mathrm{mol} / \mathrm{l})$ and LG100268 $(10 \mu \mathrm{mol} / \mathrm{l})$ displayed significant increases in glucose uptake at both basal $\left(20.3 \pm 2.3\right.$ and $18.4 \pm 1.3 \mathrm{pmol} \cdot \mathrm{mg}^{-1} \cdot \mathrm{min}^{-1}$, $p<0.01$ compared with corresponding lower concentrations, respectively) and insulin-stimulated states $(26.9 \pm 2.2$ and $24.8 \pm 1.6, p<0.01)$. After chronic treatment glucose uptake remained insulin responsive $(p<0.001$ vs treated basal values) (Fig. 1$)$. 


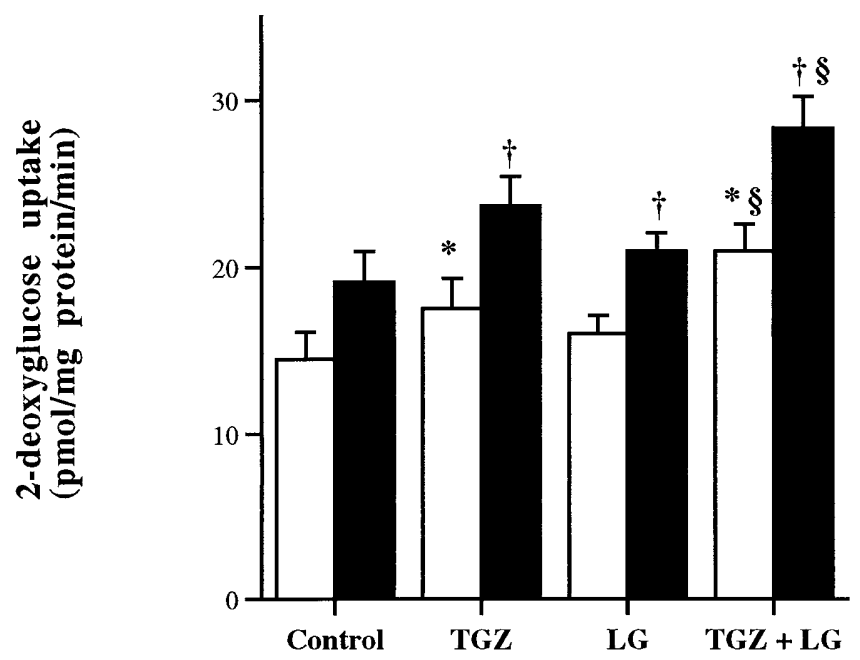

Fig. 1. Effects of troglitazone and/or LG100268 on glucose uptake activity in cultured skeletal muscle cells. Fully differentiated myotubes were treated with troglitazone $(4.6 \mu \mathrm{mol} / \mathrm{l})$ and/or LG100268 (4 $\mu \mathrm{mol} / \mathrm{l})$ for $2 \mathrm{~d}, n=16$. Basal condition $(\square)$; insulin-stimulated condition ( $\square)$ (17 nmol/l, $90 \mathrm{~min})$. Data are means + SEM. Insulin-stimulation was significant in all sets of cells $(p<0.001) * p<0.01$ vs control basal value; $\square$ $p<0.05$ vs control insulin-stimulated value; $\dagger \S<0.05$ vs troglitazone or LG100268 alone, both in basal and insulin-stimulated values, respectively

In agreement with our earlier results [22], GLUT4 protein expression $(n=12)$ was not altered after treatment with troglitazone $(113 \pm 17 \%$ of control subjects). The same was true in cells treated with LG100268 only $(125 \pm 11 \%, p=$ non significant $)$ or the combination $(127 \pm 13 \%, p=$ non significant $)$. Under the current 2-d treatment protocol, GLUT1 protein $(n=16)$ did not change with troglitazone $(89 \pm 8 \%, \quad p=$ non significant), LG100268 $(134 \pm 17 \%)$ or combination $(121 \pm 55 \%, p=$ non significant) treatment.

GS activity. Chronic troglitazone or LG100268 treatment increased both basal and insulin-stimulated GS activity and fractional velocity (FV) in muscle cells (Table 2). Combination treatment resulted in increases of the GS FV in both basal and insulin stimulated states that were greater than those seen with either treatment alone ( $p<0.05$, respectively). Fully activated/total GS activity was not altered by either agonist, on their own or in combination (Table 2).

Cells treated chronically with higher concentrations of troglitazone $(11.5 \mu \mathrm{mol} / \mathrm{l})$ and LG100268 $(10 \mu \mathrm{mol} / \mathrm{l})$ showed greater increases in GS FV both at basal $(36.0 \pm 6.2$ and $14.8 \pm 1.4 \%, p<0.05$ compared with corresponding lower concentration treatment, respectively) and at insulin-stimulated $(50.2 \pm 8.1$ and $32.6 \pm 5.8 \%, p<0.05)$ states. Insulin stimulation was still evident after treatment $(p<0.001)$.
Table 2. Chronic effects of troglitazone and LG100268 treatment on GS activity in cultured skeletal muscle cells

\begin{tabular}{|c|c|c|}
\hline Treatment & Basal & $\begin{array}{l}\text { Insulin- } \\
\text { stimulated }\end{array}$ \\
\hline $\begin{array}{l}\text { Control } \\
0.1 \mathrm{mmol} / 1 \mathrm{G}-6-\mathrm{P} \\
10 \mathrm{mmol} / \mathrm{l} \mathrm{G}-6-\mathrm{P} \\
\mathrm{FV}(\%)\end{array}$ & $\begin{array}{l}0.68 \pm 0.11 \\
6.80 \pm 1.04 \\
10.6 \pm 1.3\end{array}$ & $\begin{array}{l}1.74 \pm 0.35 \\
8.82 \pm 1.27 \\
19.5 \pm 1.7\end{array}$ \\
\hline $\begin{array}{l}\text { Troglitazone } \\
0.1 \mathrm{mmol} / \mathrm{l} \mathrm{G}-6-\mathrm{P} \\
10 \mathrm{mmol} / 1 \mathrm{G}-6-\mathrm{P} \\
\mathrm{FV}(\%)\end{array}$ & $\begin{array}{l}1.62 \pm 0.35^{*} \\
8.24 \pm 1.35 \\
19.1 \pm 2.2^{*}\end{array}$ & $\begin{array}{l}3.09 \pm 0.61 \dagger \\
10.14 \pm 1.71 \\
29.7 \pm 2.2 \dagger\end{array}$ \\
\hline $\begin{array}{l}\text { LG100268 } \\
0.1 \mathrm{mmol} / \mathrm{l} \mathrm{G}-6-\mathrm{P} \\
10 \mathrm{mmol} / 1 \mathrm{G}-6-\mathrm{P} \\
\mathrm{FV} \mathrm{( \% )}\end{array}$ & $\begin{array}{l}0.98 \pm 0.20^{*} \\
7.71 \pm 1.18 \\
12.1 \pm 2.1^{*}\end{array}$ & $\begin{array}{l}2.40 \pm 0.50 \dagger \\
8.77 \pm 1.33 \\
24.8 \pm 3.2 \dagger \dagger\end{array}$ \\
\hline $\begin{array}{l}\text { Troglitazone + LG100268 } \\
0.1 \mathrm{mmol} / \mathrm{l} \mathrm{G}-6-\mathrm{P} \\
10 \mathrm{mmol} / \mathrm{l} \mathrm{G}-6-\mathrm{P} \\
\mathrm{FV}(\%)\end{array}$ & $\begin{array}{l}1.95 \pm 0.41^{*} \ddagger \\
7.93 \pm 1.16 \\
23.8 \pm 2.3^{*} \ddagger\end{array}$ & $\begin{array}{l}3.56 \pm 0.72 \dagger \\
9.67 \pm 1.56 \\
35.2 \pm 4.1 \dagger \dagger\end{array}$ \\
\hline
\end{tabular}

Data are mean \pm SEM. Fully differentiated myotubes were treated with troglitazone $(4.6 \mu \mathrm{mol} / \mathrm{l})$ and/or LG100268 ( $4 \mu \mathrm{mol} / \mathrm{l})$ for 2 days. A total of 15 measurements were done in duplicate for each condition. In the basal state, no insulin was added to serum-free media. In the stimulated state, insulin ( $17 \mathrm{nmol} / \mathrm{l})$ was added to serum-free media for $90 \mathrm{~min}$. The GS results at 0.1 and $10 \mathrm{mmol} / 1 \mathrm{G} 6 \mathrm{P}$ are expressed as nanomoles per milligram of protein per min. FV, fractional velocity defined as percentage of GS activity at 0.1 and $10 \mathrm{mmol} / \mathrm{l} \mathrm{G6P.} \mathrm{In-}$ sulin-stimulation was significant both in GS activity at $0.1 \mathrm{mmol} / \mathrm{l} \mathrm{G} 6 \mathrm{P}$ and $\mathrm{FV}$ in all sets of cells $(p<0.01)$

$* p<0.05$ vs control basal value;

$\dagger p<0.05$ vs control insulin-stimulated value;

$\ddagger p<0.05$ vs either troglitazone or LG100268 alone both in basal and insulin-stimulated values, respectively

Palmitate oxidation. Chronic treatment with troglitazone $(1.06 \pm 0.13 \mathrm{nmol} / \mathrm{mg}$ protein $/ 3 \mathrm{~h}, 68 \pm 23 \%$ increase) or LG100268 $(1.03 \pm 0.11,53 \pm 12 \%$ increase) alone significantly increased palmitate oxidation compared with control cells $(0.64 \pm 0.06$, $p<0.005$, respectively). A synergistic increase, to more than double the control activity, was observed after chronic treatment with both agents $(1.46 \pm 0.17,146 \pm 38 \%$ increase, $p<0.005$ compared with either agent alone or the sum of both individual treatments).

Troglitazone treatment alone increased palmitate oxidation in a dose-dependent manner. Addition of LG100268 (4 $\mu \mathrm{mol} / \mathrm{l})$ shifted the curve upward, with the greatest effect at the highest troglitazone concentration (Fig.3A). The dose-responsive curve for LG100268 treatment on palmitate oxidation was also shifted upwards with the addition of troglitazone $(4.6 \mu \mathrm{mol} / \mathrm{l})$ (Fig. 3B). The sensitivity of muscle cells to one agent was unaltered by co-treatment with the other agent.

Beta oxidation of fatty acids can occur at mitochondrial, peroxisomal or undefined sites and through several mechanisms in the muscle cell [23]. By the opera- 


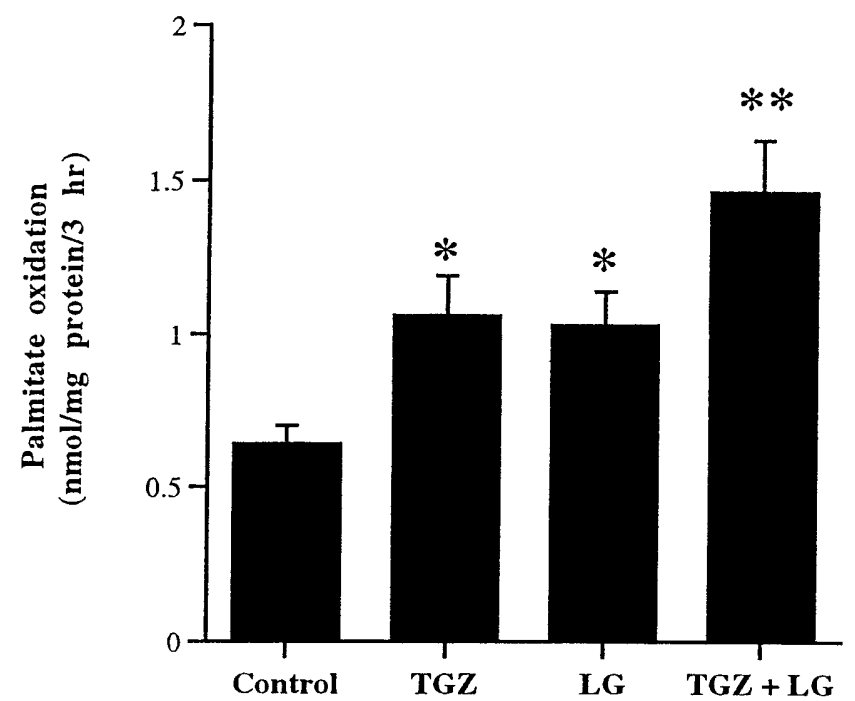

Fig. 2. Effects of troglitazone and/or LG100268 treatment on palmitate oxidation activity in cultured skeletal muscle cells. Fully differentiated myotubes were treated with troglitazone $(4.6 \mu \mathrm{mol} / \mathrm{l})$ and/or LG100268 $(4 \mu \mathrm{mol} / \mathrm{l})$ for 2 days, $n=22$. Data are mean + SEM. * $p<0.01$ vs control value; ** $p<0.001$ vs troglitazone or LG100268 alone values, respectively

tional definition described in the Methods section, about half $(43 \pm 4 \%)$ of the beta-oxidation of palmitate in control HSMC occurred in mitochondria (Fig. 4), $26 \pm 4 \%$ through peroxisomes and the rest by undefined processes. Troglitazone stimulation of palmitate oxidation seemed to involve primarily the mitochondrial pathway ( $p<0.0005$ compared to control subjects). There was no significant difference in the peroxisomal component (Fig. 4). With LG100268 treatment both the mitochondrial $(p<0.01)$ and peroxisomal $(p<0.05)$ components increased. The same was true after combination treatment.

The initial step in palmitate oxidation, entry into the cell, is mediated in part by several proteins, including the Fatty Acid Transporter (FAT/CD36) [24]. The FAT protein was present as a MW of about $88 \mathrm{kDa}$ protein in human muscle cells (Fig. 5). Expression of FAT/CD36 protein was upregulated following treatment with troglitazone $(4.6 \mu \mathrm{mol} / \mathrm{l}$, $113 \pm 41 \%$ increase over control subjects, $p<0.025)$ or LG100268 $(4 \mu \mathrm{mol} / 1, \quad 91 \pm 36 \%$ increase, $p<0.025)$.

Potential regulation of nuclear receptors. The PPAR $\gamma$ protein expression increased in cells treated with troglitazone alone $(69 \pm 26 \%$ increase over control subjects, $p<0.05$ compared with control subjects). Adding LG100268 resulted in no further change in PPAR $\gamma$ levels $(51 \pm 20 \%$ over control subjects, $p<0.05)$. All three $\mathrm{RXR}$ isoforms were present in human muscle cells (Fig.6). Protein expression of the isoforms; $\mathrm{RXR} \alpha(\mathrm{MW} \sim 44 \mathrm{kDa}, n=19), \mathrm{RXR} \beta$
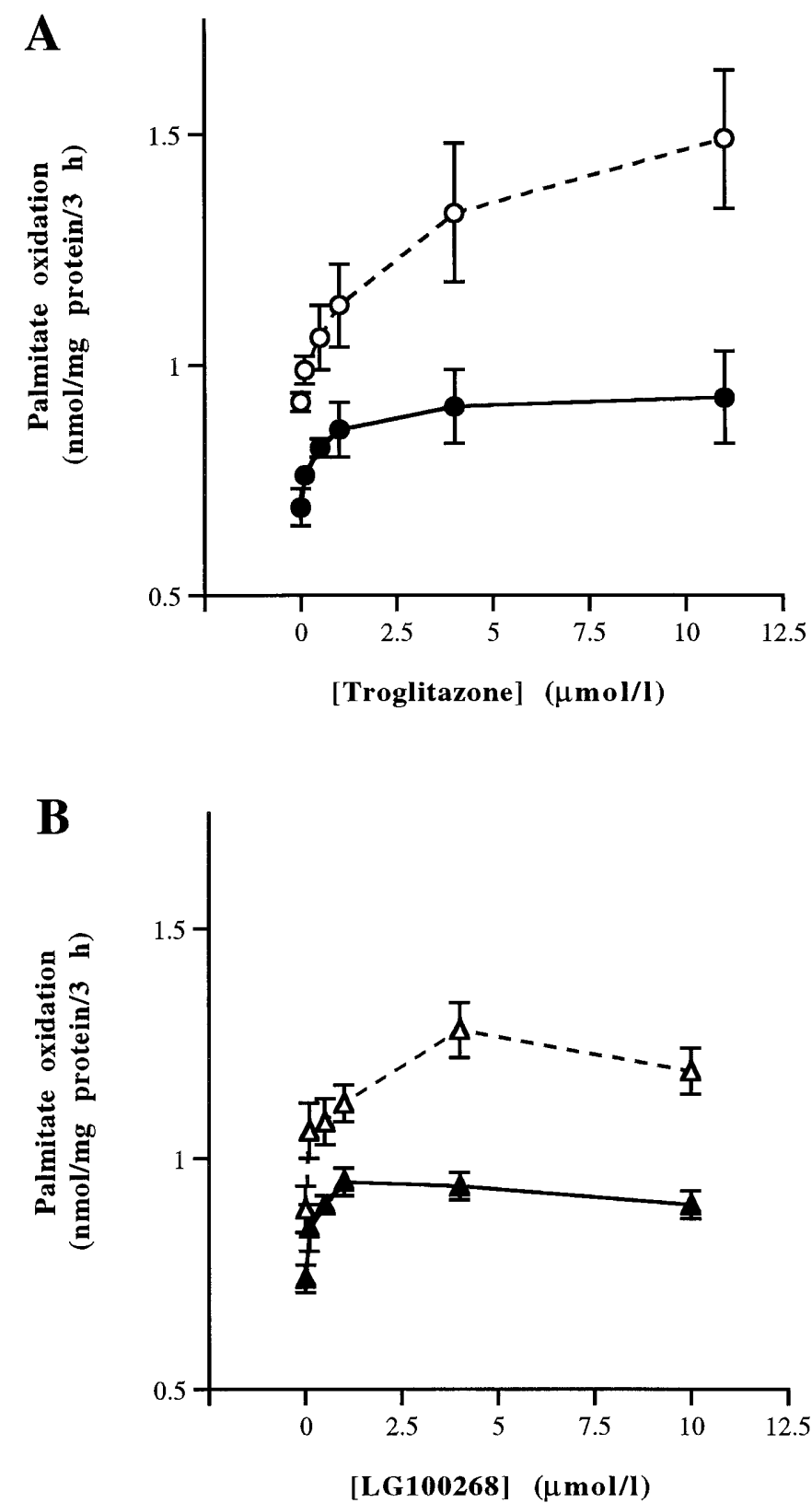

Fig.3 A, B. Dose-response curves of chronic troglitazone or LG100268 treatment or both on palmitate oxidation in cultured skeletal muscle cells. A fully differentiated myotubes $(n=4)$ were treated with different concentration of troglitazone $(0.1 \sim 11.5 \mu \mathrm{mol} / \mathrm{l})$ alone $(-)$ or with fixed concentration of LG100268 (4 $4 \mathrm{~mol} / 1,---)$. B Fully differentiated myotubes $(n=4)$ were treated with different concentration of LG100268 $(0.1 \sim 10.0 \mu \mathrm{mol} / \mathrm{l})$ alone (solid line) or with fixed concentration of troglitazone $(4.6 \mathrm{~mol} / \mathrm{l}$, dotted line $)$. Data are means \pm SEM

$(\mathrm{MW} \sim 36 \mathrm{kDa} n=9), \mathrm{RXR} \gamma(\mathrm{MW} \sim 54 \mathrm{kDa} n=8)$, as well as PPAR $\alpha(n=15)$ did not differ significantly from control after treatment with troglitazone and/ or LG100268 (not shown). 


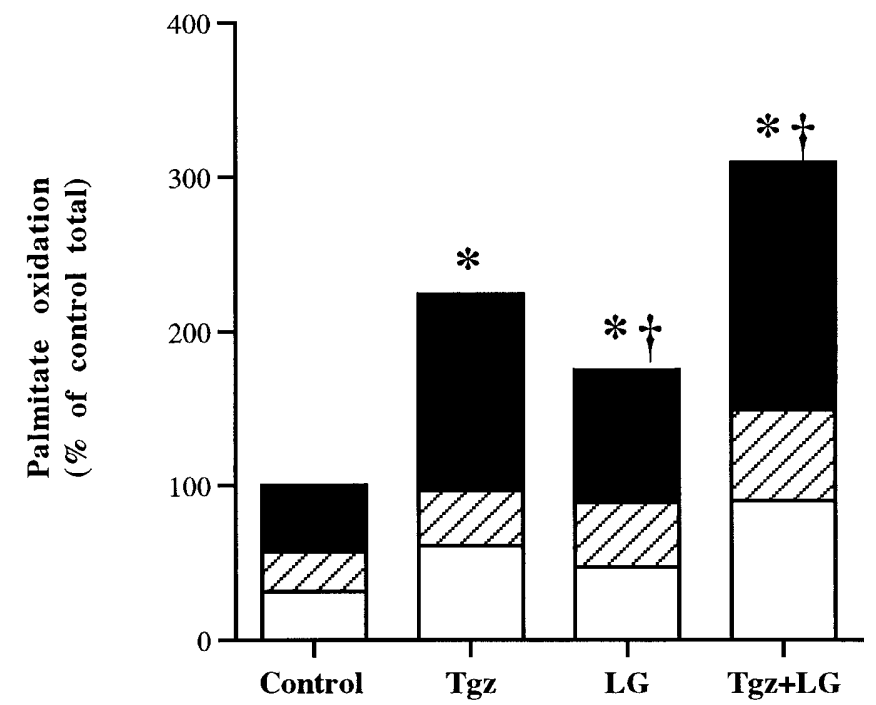

Fig. 4. Effects of troglitazone and/or LG100268 treatment on components of palmitate oxidation in cultured human skeletal muscle cells. Mitochondrial component ( $\square$ ), peroxisomal component (U), other/undefinied component $(\square)$. Operational definition of components is presented in Methods. Results expressed as percentage of the total palmitate oxidation in control cells for each individual. Results are average, $n=8$ for Tgz + LG group, $n=13$ for all other conditions $* p<0.05$ vs control for mitochondrial palmitate oxidation; $\uparrow p<0.05$ vs control for peroxisomal oxidation

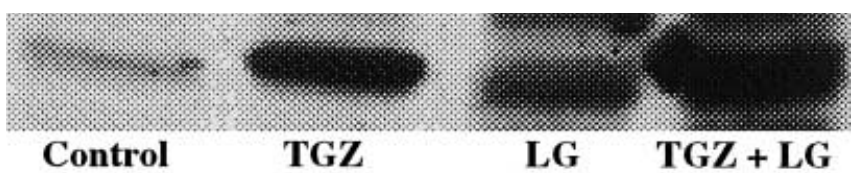

Fig.5. Effects of troglitazone or LG100268 treatment or both on FAT/CD36 protein expression in human skeletal muscle cells. Cells were treated for 2 days with troglitazone (Tgz, $4.6 \mu \mathrm{mol} / \mathrm{l})$, LG100268 (LG, $4 \mu \mathrm{mol} / \mathrm{l}$ ) or the combination. Representative western blot

\section{Discussion}

Thiazolidinediones, including troglitazone, rosiglitazone and pioglitazone, are a new family of potent antidiabetic agents which act as insulin sensitizers [3, 26]. Apart from effects on blood glucose and insulin concentrations, thiazolidinedione treatment also affects dyslipidaemia [27, 28]. A key event in understanding the potential mechanisms of action of these compounds was the observation that thiazolidinediones are artificial ligands for PPAR $\gamma$ [29]. These results suggest that many of the actions of thiazolidinediones occur through PPAR $\gamma[4,26]$. That PPAR response elements are contained in the promoter regions of key genes involved in lipid and glucose metabolism is further support for this hypothesis $[4,6$, $30,31]$. The PPAR $\gamma$ regulation of gene transcription occurs only through the formation of heterodimer with RXR [32]. Indeed, RXR specific ligands can act

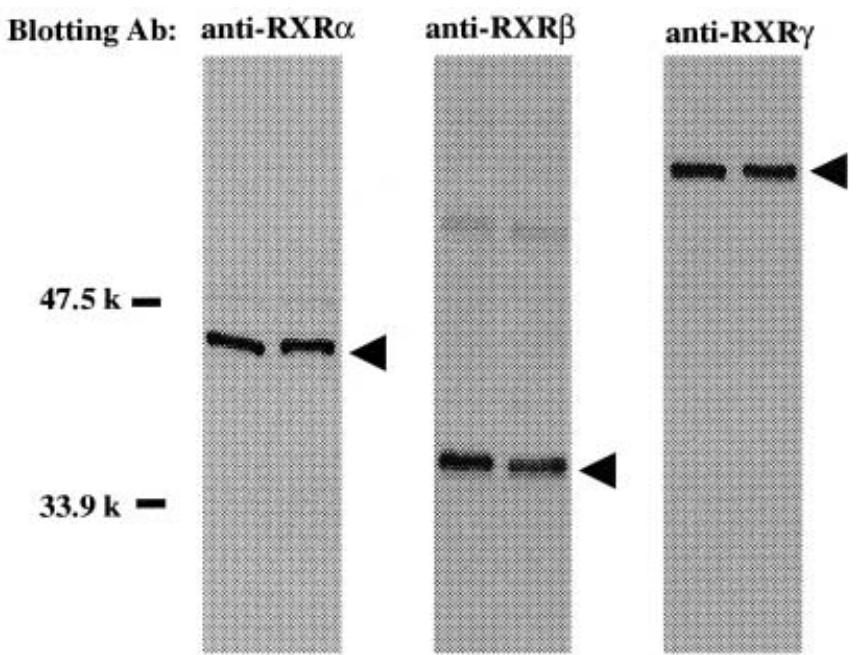

Fig. 6. $\mathrm{RXR} \alpha, \mathrm{RXR} \beta$, and $\mathrm{RXR} \gamma$ protein expression in differentiated cultured human skeletal muscle cells. Representative western blot of cells from two individual subjects

together with $\operatorname{PPAR} \gamma$ ligands to regulate reporter gene expression [33]. Of note, in addition to that property, synthetic RXR ligands (LG100268, Ligand Corp., San Diego, Calif., USA) have also been shown to have hypoglycaemic effects in diabetic animals [9], possibly in combination with endogenous PPAR $\gamma$ ligands. Little is, however, known about the possible independent or synergistic effects of RXR ligands on metabolism in skeletal muscle, a physiologically relevant tissue.

To investigate possible interactivity with LG100268, studies were done at a submaximal troglitazone dose $(2 \mu \mathrm{g} / \mathrm{ml}=4.6 \mu \mathrm{mol} / \mathrm{l})$. Studies in healthy volunteers have shown that oral troglitazone administration (400 $\mathrm{mg}$ twice daily for $7 \mathrm{~d}$ ) resulted in a steady state plasma concentration of about $2 \mu \mathrm{g} / \mathrm{ml}$ [34], a dose in the therapeutic range. Concentrations of LG100268 for initial study were chosen to be equimolar with troglitazone.

Troglitazone and LG100268 upregulated glucose uptake following chronic treatment. Both basal and insulin-stimulated uptake were raised, indicating increased insulin responsiveness. On a molar basis troglitazone was the more potent agent for this response. Combining the agents at submaximal concentrations increased uptake in an apparently synergistic manner greater than the sum of the individual effects. We have previously shown that glucose uptake in muscle cells from Type II diabetic subjects is 50 to $60 \%$ of the activity in non-diabetic muscle cells [12]. An increase in diabetic muscle cells of the magnitude seen here from combination treatment could essentially normalise glucose uptake in diabetic cells.

When added, only troglitazone was more potent than LG100286 on glycogen synthase activation state (FV). Insulin responsiveness was also augmented. Glycogen synthase activity (FV) in diabetic muscle 
cells is half that seen in non-diabetic cells [11]. The doubling of FV, both basal and insulin-stimulated, that occurs after combination treatment (Table 2) could effectively normalize glycogen synthase activity in diabetic muscle. The ability of LG100268 + troglitazone to raise both glucose uptake and glycogen synthase activities in a major insulin target tissue could provide a partial cellular explanation for the hypoglycaemic actions of these agents, together with effects in adipose tissue [4].

The capacity of troglitazone and LG100268 to increase skeletal muscle lipid oxidation is a novel observation in human muscle cells and is consistent with reductions in lipid concentrations following in vivo treatment [9]. Augmented skeletal muscle lipid utilization could contribute to this response. In agreement with this conjecture is the observation that troglitazone treatment of Zucker diabetic fatty rats increases palmitate oxidation in soleus muscle [35]. In addition, PPREs have been identified on several key genes involved in the beta-oxidation of lipids [28, 36, 37], as well as FAT/CD36 [38]. The response of palmitate oxidation to treatment with troglitazone and LG100268 differs in several ways from glucose uptake and glycogen synthase. First, the relative increases resulting from treatment with either agent alone were greater for palmitate oxidation than for glucose uptake. Palmitate oxidation was also more sensitive to the agents than to glucose uptake or glycogen synthase. In considering possible explanations for this, it is important to consider that in addition to effects on PPAR $\gamma:$ RXR heterodimers, LG100268 can also activate PPAR $\alpha: R X R$ heterodimers [39] and RXR homodimers [8], all of which might lead to enhanced fatty acid oxidation independent of a PPAR $\gamma$ activator. The RXR $\alpha$ has been shown to activate the transcription of the genes encoding medium chain acyl-CoA dehydrogenase [40] and muscle-type carnitine palmitoyltransferase 1 (CPT-1 [41]), two key enzymes related to mitochondrial fatty acid oxidation.

Lipid oxidation as measured in this report would represent the sum of a number of processes, including fatty acid uptake, fatty acid activation/acylation, entry into mitochondria via CPT1 and beta-oxidation [42]. If multiple nuclear receptor complexes are involved in the control of lipid oxidation, it is possible that each regulates genes responsible for different processes. An example of this behavior might be the observation that LG100268 treatment influenced both mitochondrial and peroxisomal palmitate oxidation while troglitazone affected only the mitochondrial component. Indeed, troglitazone has been shown to increase fatty acid uptake [38, 39] while PPAR $\alpha$ agonists increase enzymes involved in beta-oxidation $[42,43]$. The multiple routes for an RXR agonist to influence lipid oxidation could explain the greater potency and sensitivity of LG100268 on lipid oxidation than on glucose metabolism.
A recent report may shed further light on the mechanisms by which troglitazone and LG100268 influences lipid oxidation. The FAT/CD36 was overexpressed in muscle and increases in both FFA uptake and palmitate oxidation observed [44]. Lipid accumulation in muscle was not observed, suggesting that palmitate was directed toward oxidation. The increase of FAT in HSMC following troglitazone and LG100268 treatment had a similar effect on palmitate oxidation. The LG100268, along with other RXR agonists, has also been shown to upregulate the expression of Fatty Acid Transport Protein 1 [45], indicating another possible mechanism for controlling lipid utilization.

One observed response of human muscle cells to troglitazone treatment is upregulation of PPAR $\gamma$ expression [25]. While increases in PPAR $\gamma$ protein after troglitazone were confirmed in our study, this response was not potentiated by LG100268. Thus, the amount of PPAR $\gamma$ protein could not explain the synergism observed in this report. In contrast to troglitazone, LG100268 treatment did not regulate the expression of any of the isoforms $(\mathrm{RXR} \alpha, \operatorname{RXR} \beta$, and $\operatorname{RXR} \gamma)$ of its cognate receptor. These results are compatible with our observation that RXR $\alpha$ mRNA and protein concentrations in skeletal muscle did not differ between normal and diabetic subjects and had no correlation with PPAR $\gamma$ expression or metabolic parameters [46], suggesting that $\mathrm{RXR} \alpha$ expression might not be a key level of control, at least in muscle, although regulation of RXR expression has been reported in liver [47] and cultured adipocytes [48], further evidence for tissue specificity in the control of RXR expression.

In conclusion, the RXR agonist LG100268 has a potent effect on increasing glucose uptake, GS activity and palmitate oxidation in human skeletal muscle cells. Furthermore, in the presence of troglitazone, LG100268 can enhance the utilization of carbohydrate and lipid. The potential of skeletal muscle to respond to treatment with increases in glucose and lipid utilization could, together with documented responses in adipose tissue [4], and possibly liver, contribute to the ability of the combination of LG100268 and a thiazolidinedione to reduce glucose and triglyceride concentration in diabetic animals [9]. The seeming paradox of increases in both glucose and lipid utilization in response to treatment could be resolved if, over the time frame $(3 \mathrm{~h})$ of the assay, it is palmitate that is primarily oxidized to meet the energy needs of the cell while the increase of non-oxidative glucose disposal (as storage into glycogen) would provide stores for future needs. The specific patterns of metabolic responses in different tissues would depend upon the presence of ligands for different nuclear receptors. The ability of troglitazone and LG100268 to influence the expression of FAT/CD36, a PPRE controlled gene, provides indirect support of the conclu- 
sions derived from studies using reporter systems [9, 33], that PPAR $\gamma$ and RXR agonists work together to control the expression of PPRE containing genes. These studies suggest that RXR agonists have direct effects on an important insulin sensitive tissue and have considerable potential as possible therapeutic agents, working on both adipose tissue and muscle, to reduce hyperglycaemia and hyperlipidaemia, especially when combined with PPAR $\gamma$ agonists.

Acknowledgements. This work was supported by funds from the Medical Research Service, Department of Veterans Affairs, the Veterans San Diego Healthcare System, a Career Development Award from American Diabetes Association (SEN), the Whittier Institute for Diabetes, and Grant MO1 RR-00827 from the General Clinical Research Centers Program, National Center for Research Resources, NIH. T.P. Ciaraldi and S. Mudaliar are members of the Parke-Davis Speakers Bureau, R.R. Henry is a consultant for and has received research support from Parke-Davis Pharmaceuticals.

\section{References}

1. DeFronzo RA, Bonadonna RC, Ferrannini E (1992) Pathogenesis of NIDDM. A balanced overview. Diabetes Care 15: 318-368

2. Baron AD, Laasko M, Breechtel G et al. (1991) Reduced capacity and affinity of skeletal muscle for insulin-mediated glucose uptake in non-insulin dependent diabetic subjects. J Clin Invest 87: 1186-1194

3. Willson TM, Wahli W (1997) Peroxisome proliferator-activated receptor agonists. Curr Opin Chem Biol 1: 235-241

4. Auwerx J (1999) PPARgamma, the ultimate thrifty gene. Diabetologia 42: 1033-1049

5. Kliewer SA, Umesono K, Noonan DJ et al. (1992) Convergence of 9-cis retinoic acid and peroxisome proliferator signaling pathways through heterodimer formation of their receptors. Nature 358: 771-774

6. Castelein H, Gulick T, Declercq PE et al. (1994) The peroxisome proliferator activated receptor regulates malic enzyme gene expression. J Biol Chem 269: 26754-26758

7. Tontonoz P, Hu E, Devine J et al. (1995) PPAR $\gamma 2$ regulates adipose expression of the phosphoenolpyruvate carboxykinase gene. Mol Cell Biol 15: 351-357

8. Mangelsdorf DJ, Evans RM (1995) The RXR heterodimers and orphan receptors. Cell 83: 841-850

9. Mukherjee R, Davies PJ, Crombie D et al. (1997) Sensitization of diabetic and obese mice to insulin by retinoid $\mathrm{X}$ receptor agonists. Nature 386: 407-410

10. Schulman IG, Shao G, Heyman RA (1998) Transactivation by retinoid $\mathrm{X}$ receptor- peroxisome proliferator-activated receptor $\gamma(\operatorname{PPAR} \gamma)$ heterodimers: Intermolecular synergy requires only the PPAR $\gamma$ hormone-dependent activation function. Mol Cell Biol 18: 3483-3494

11. Henry RR, Ciaraldi TP, Abrams-Carter L et al. (1996) Glycogen synthase activity is reduced in cultured skeletal muscle cells of NIDDM subjects: biochemical and molecular mechanisms. J Clin Invest 98: 1231-1236

12. Henry RR, Abrams L, Nikoulina S et al. (1995) Insulin action and glucose metabolism in non-diabetic control and NIDDM subjects: comparison using human skeletal muscle cell cultures. Diabetes 44: 936-946
13. National Diabetes Data Group (1979) Classification and diagnosis of diabetes mellitus and other categories of glucose tolerance. Diabetes 28: 1039-1057

14. Thorburn AW, Gumbiner B, Bulacan F et al. (1991) Multiple defects in muscle glycogen synthase activity contribute to reduced glycogen synthesis in non-insulin dependent diabetes mellitus. J Clin Invest 87: 489-495

15. Blau HM, Webster C (1981) Isolation and characterization of human muscle cells. Proc Natl Acad Sci U S A 78: 5623-5627

16. Sarabia V, Lam L, Burdett E et al. (1990) Glucose uptake in human and animal muscle cells in culture. Biochem Cell Biol 68: 536-542

17. Klip A, Li G, Logan WJ (1984) Induction of sugar uptake response to insulin by serum depletion in fusing L6 myoblast. Am J Physiol 247: E291-E296

18. Bradford MM (1976) A rapid and sensitive method for the quantitation of protein utilizing the principle of proteindye binding. Anal Biochem 71: 248-254

19. Rognstad R (1991) Estimation of peroxisomal and mitochondrial fatty acid oxidation in rat hepatocytes using tritiated substrates. Biochem J 279: 147-150

20. Bhuiyan AKM, Murthy MSR, Pande SV (1994) Some properties of the malonyl-CoA sensitive carnitine long/ medium chain acyltransferase activities of peroxisomes and microsomes of rat liver. Biochem Mol Biol Intl 34: 493-503

21. Towbin H, Staehelin T, Gorden J (1979) Electrophoretic transfer of protein from polyacrylamide gels to nitrocellulose sheets: Procedure and some applications. Proc Natl Acad Sci U S A 76: 4350-4354

22. Park KS, Ciaraldi TP, Abrams-Carter L et al. (1998) Troglitazone regulation of glucose metabolism in human skeletal muscle cultures from obese type II diabetic subjects. J Clin Endocrinol Metab 83: 1636-1643

23. Lee WN, Lim S, Bassilian S et al. (1998) Fatty acid cycling in human hepatoma cells and the effects of troglitazone. J Biol Chem 273: 20929-20934

24. Sfeir Z, Ibrahimi A, Amri E et al. (1997) Regulation of FAT/CD36 gene expression: further evidence in support of a role of the protein in fatty acid binding/transport. Prostaglandins, Leukot Essent Fatty Acids 57: 17-21

25. Park KS, Ciaraldi TP, Lindgren K et al. (1998) Troglitazone effects on gene expression in human skeletal muscle of type II diabetes involve up-regulation of peroxisome proliferator-activated receptor- $\gamma$. J Clin Endocrinol Metab 83: 2830-2835

26. Spiegelman BM (1998) PPAR- $\gamma$ : adipogenic regulator and thiazolidinedione receptor. Diabetes 47: 507-514

27. Fulgencio JP, Kohl C, Girard J et al. (1996) Troglitazone inhibits fatty acid oxidation and esterification, and gluconeogenesis in isolated hepatocytes from starved rats. Diabetes 45: $1556-1562$

28. Gulick T, Cresci S, Caira T et al. (1994) The peroxisome proliferator-activated receptor regulates mitochondrial fatty acid oxidative enzymes gene expression. Proc Natl Acad Sci U S A 91: 11012-11016

29. Lehmann JM, Moore LB, Smith-Oliver TA et al. (1995) An antidiabetic thiazolidinedione is a high affinity ligand for peroxisome proliferator-activated receptor $\gamma$ (PPAR $\gamma)$. J Biol Chem 270: 12953-12956

30. Varanasi U, Chu R, Huang Q et al. (1996) Identification of a peroxisome proliferator-responsive element upstream of the human peroxisomal fatty acyl coenzyme A oxidase gene. J Biol Chem 271: 2147-2155

31. Schoonjans K, Watanabe M, Suzuki H et al. (1995) Induction of the acyl-CoA synthethase gene by fibrate and fatty 
acids is mediated by a peroxisome proliferator response element in the C promoter. J Biol Chem 270: 19269-19276

32. Ijpenberg A, Jeannin E, Wahli W et al. (1997) Polarity and specific sequence requirements of peroxisome proliferator-activated receptor (PPAR)/retinoid X receptor heterodimer binding to DNA. A functional analysis of the malic enzyme gene PPAR response element. J Biol Chem 272: 20108-20117

33. Mukherjee R, Jow L, Croston GE et al. (1997) Identification, characterization, and tissue distribution of human peroxisome proliferator-activated receptor (PPAR) isoforms PPAR $\gamma 2$ versus PPAR $\gamma 1$ and activation with retinoid $\mathrm{X}$ receptor agonists and antagonists. J Biol Chem 272: 8071-8076

34. Shibata H, Nii S, Kobayashi M et al. (1993) Phase I study of a new hypoglycemic agent CS-045 in healthy volunteers. Safety and pharmacokinetics in repeated administration. Rinsho Iyaku 9: 1519-1537

35. Ide T, Nakazawa T, Mochizuki T et al. (2000) Tissue-specific actions of antidiabetic thiazolidinediones on the reduced fatty acid oxidation in skeletal muscle and liver of Zucker diabetic fatty rats. Metabolism 49: 521-525

36. Latruffe N, Vamecq J (1997) Peroxisome proliferators and peroxisome proliferator activated receptors (PPARs) as regulators of lipid metabolism. Biochimie 79: 81-94

37. Motojima K, Passilly P, Peters JM et al. (1998) Expression of putative fatty acid transporter genes are regulated by peroxisome proliferator-activated receptor $\alpha$ and $\gamma$ activators in a tissue- and inducer-specific manner. J Biol Chem 273: $16710-16714$

38. Schoonjans K, Peinado-Onsurbe J, Lefevre AM et al. (1996) PPARalpha and PPARgamma activators direct a distinct tissue-specific transcriptional response via a PPRE in the lipoprotein lipase gene. EMBO J 15: 5336-5348

39. Mukherjee R, Strasser J, Jow L et al. (1998) RXR agonists activate PPAR $\alpha$-inducible genes, lower triglycerides, and raise HDL levels in vivo. Arterioscler Thromb Vasc Biol 18: 272-276

40. Raisher BD, Gulick T, Zhang Z et al. (1992) Identification of a novel retinoid-responsive element in the promoter re- gion of the medium chain acyl-coenzyme A dehydrogenase gene. J Biol Chem 267: 20264-20269

41. Brandt JM, Djouadi F, Kelly DP (1998) Fatty acids activate transcription of the muscle carnitine palmitoyltransferase 1 gene in cardiac myocytes via the peroxisome proliferatoractivated receptor $\alpha$. J Biol Chem 273: 23786-23792

42. Campbell PJ, Carlson MG, Hill JO et al. (1992) Regulation of free fatty acid metabolism by insulin in humans: Role of lypoysis and reesterification. Am J Physiol 263: E1063-E1069

43. Asayama K, Sandhir R, Sheikh FG et al. (1999) Increased peroxisomal fatty acid beta-oxidation and enhanced expression of peroxisome proliferator-activated receptor-alpha in diabetic rat liver. Mol Cell Biochem 194: 227-234

44. Ibrahimi A, Bonen A, Blinn WD et al. (1999) Muscle-specific overexpression of FAT/CD36 enhances fatty acid oxidation by contracting muscle, reduces plasma triglycerides and fatty acids, and increases plasma glucose and insulin. J Biol Chem 274: 26761-26766

45. Martin G, Poirier H, Hennuyer N et al. (2000) Induction of the fatty acid transport protein 1 and acyl-Co-A synthase genes by dimer-selective rexinoids suggests that the peroxisome proliferator-actyivated receptor-retinoid $\mathrm{X}$ receptorheterodimer is their molecular target. J Biol Chem 275: 12612-12619

46. Codner E, Ciaraldi TP, Rehman N et al. (1999) Evaluation of retinoid X receptor $\alpha(\mathrm{RXR} \alpha)$ mRNA and protein expression in skeletal muscle of non-diabetic, obese and Type II diabetic individuals. Endocrinology 140 [Suppl 1]: 123 A (Abstract)

47. Steineger HH, Arnsten BM, Spydevold O et al. (1998) Gene transcription of the retinoid $X$ receptor alpha ( $\mathrm{RXRa}$ ) is regulated by fatty acids and hormones in rat hepatic cells. J.Lipid Res 39: 744-754

48. Hauser S, Adelmant G, Sarraf P et al. (2000) Degradation of the peroxisome proliferator-activated receptor $\gamma$ is linked to ligand-dependent activation. J Biol Chem 275: 18527-18533 